NBER WORKING PAPER SERIES

\title{
THE INCIDENCE OF EXTREME ECONOMIC STRESS: EVIDENCE FROM UTILITY DISCONNECTIONS
}

\author{
Steve Cicala \\ Working Paper 28422 \\ http://www.nber.org/papers/w28422 \\ NATIONAL BUREAU OF ECONOMIC RESEARCH \\ 1050 Massachusetts Avenue \\ Cambridge, MA 02138 \\ January 2021
}

I am grateful to Josh Gottlieb, Peter Ganong, and Matthew Notowidigdo for helpful comments. I thank Daisy Lu for excellent research assistance, and Jim Zolnierek at the Illinois Commerce Commission for help with the data. This paper is based on work supported by the Sloan Foundation and the National Science Foundation under Grant No. SES-2031184. All errors remain my own. e-mail: scicala@gmail.com. The views expressed herein are those of the author and do not necessarily reflect the views of the National Bureau of Economic Research.

NBER working papers are circulated for discussion and comment purposes. They have not been peer-reviewed or been subject to the review by the NBER Board of Directors that accompanies official NBER publications.

(C) 2021 by Steve Cicala. All rights reserved. Short sections of text, not to exceed two paragraphs, may be quoted without explicit permission provided that full credit, including $\bigcirc$ notice, is given to the source. 
The Incidence of Extreme Economic Stress: Evidence from Utility Disconnections

Steve Cicala

NBER Working Paper No. 28422

January 2021

JEL No. G51,I30,L94,Q40

\begin{abstract}
$\underline{\text { ABSTRACT }}$
This paper uses monthly zip code-level data on electricity disconnections to document the socioeconomic correlates of extreme economic distress among 5 million customers in Illinois. In 2018-2019, customers in Black and Hispanic zip codes were about 4 times more likely to be disconnected for non-payment, 2-3 times more likely to be on deferred payment plans, and 70\% more likely to participate in utility-based low-income assistance programs, controlling for zip code distributions of income and other demographic characteristics. During the COVID-19 pandemic, there has been a nine-fold expansion in low-income assistance to pay utility bills, but disconnections were double and deferred payment plans triple their historical averages in October 2020. Disconnection notices were served to $2.5 \%$ of commercial and industrial accounts, and $3.4 \%$ of residential accounts each month in late 2020 . About $20 \%$ of all accounts were charged late fees. The odds for each of these measures were multiples higher in minority and low-income zip codes.
\end{abstract}

Steve Cicala

Tufts University

Department of Economics

Braker Hall

Room 317

8 Upper Campus Rd.

Medford, MA 02155

and NBER

scicala@gmail.com 


\section{Introduction}

Having one's power cut due to non-payment ceases access to modern life's basic necessities: light, refrigeration, telecommunications, and often heat to name a few. Beyond mere conveniences, access to heating and cooling are important predictors of mortality (Barreca et al. (2016); Chirakijja et al. (2020)). This is especially the case during the COVID-19 pandemic (Jowers et al. (2021)) as utilities constrain one's ability to stay at home (Wright et al. (2020)). Lack of electricity also has especially acute consequences for children during periods of remote, computer-based education. While definitions of extreme poverty typically focus on dollar-based income and consumption thresholds (the widely-cited World Bank global poverty line is $\$ 1.90$ per person, per day), there is a reasonable case to be made that lack of electricity is a sufficient condition. This paper tracks the incidence of electricity disconnections and other utility-based indicators of economic stress at the monthly-zip code level in Illinois and documents the disproportionate burden experienced by low-income and minority communities.

Both survey-based and administrative approaches to measuring extreme economic distress have distinct shortcomings. Surveys increasingly suffer from non-response, as well as the under-reporting of income and transfers (Meyer et al. (2015)). Administrative datasets may miss those who are disconnected from formal employment and the social safety net. A recent major undertaking to link survey responses to administrative data has sought to improve the quality of data on extreme poverty in the United States (Medalia et al. (2019); Meyer et al. (2021)), but high-frequency and spatially disaggregated measurements remain elusive. Given the general preference for consumptionrather than income-based measurements of poverty (Meyer and Sullivan (2003)), the foundational role electricity plays in the consumption of a bundle of essential goods highlights the potential value of power disconnections as an indicator of extreme economic distress. ${ }^{1}$

I connect zip code-level data on disconnections, deferred payment agreements (DPAs), and participation in utility-based low-income assistance programs from Illinois' two largest utilities with demographic data from the U.S. Census Bureau's American Community Survey for over 1,300 zip codes. These data cover roughly five million households. I study two distinct periods, 2018-2019, and from September-December during the COVID-19 pandemic. Using logistic regressions that control for zip code distributions of income and other demographic characteristics, I find that the odds of being disconnected for non-payment are four times higher for customers in Black and Hispanic zip codes. Customers in these zip codes are 2-3 times more likely to be on deferred payment plans, and $70 \%$ more likely to participate in low-income assistance programs for electricity.

There has been a troubling increase in disconnections and deferred payment agreements during the COVID-19 pandemic. Though utilities announced a voluntary extension of disconnection moratoria for customers in economic distress, nearly $1 \%$ of all accounts were disconnected for non-payment in October 2020 (twice the usual amount). There has been a three-fold rise in deferred payment agreements. These increases have occurred in spite of a nine-fold expansion in low-income assistance. Utilities have been reporting additional outcomes during the COVID-19 pandemic, including details for 600,000 commercial and industrial customers. Each month from September-December

\footnotetext{
${ }^{1}$ Disconnections are a flow measure of the gross increase of customers without power (a stock). Absent an initial number of customers without power and statistics on reconnections, the stock is unobserved. However, disconnections become a better measure of the size of the disconnected population when long-term reconnection rates are high. Historical data from Commonwealth Edison report that about $75 \%$ of disconnections for non-payment are reconnected within 12 months.
} 
2020 , about $20 \%$ of all accounts were charged non-payment fees, and disconnection notices were served to $3.4 \%$ and $2.5 \%$ of residential and commercial/industrial accounts, respectively. For each of these outcomes there is a strong disproportionate burden on minority communities.

This paper reinforces recent work that has found the economic burden of the COVID-19 pandemic has fallen disproportionately on low-income and minority communities (Chetty et al. (2020); Baum et al. (2020); Couch et al. (2020); Han et al. (2020)) and documented an expansion of the social safety net (Cox et al. (2020)) that failed to buffer the impact for some of the most needy (Bitler et al. (2020)). It is also complementary to recent surveys on energy insecurity during the pandemic (Carley and Konisky (2020); Graff and Carley (2020)). The data from electric utilities, however, yield greater statistical power than surveys (to allow fine geographic mapping of outcomes, in particular), higher reporting frequency than annual administrative data, and broader coverage than electronic payment-based surveillance systems. Collection from additional states is underway.

To be clear, this study does not reveal bias in utilities' treatment of poor and minority customers: Individual usage, payments, and balances are unobserved. My results would be consistent with utilities determining disconnections based upon billing and payments alone if customers in lowincome and minority communities are more likely to fall farther behind on their utility bills holding the distribution of income fixed and other demographic variables. Instead of identifying any potential unequal treatment by utilities, this study reveals the disproportionate economic stress experienced in these communities, both in normal times, and especially during the COVID-19 pandemic.

The paper is organized as follows: I first describe the data sources in section 2 , then the econometric methods I employ in section 3. The fourth section presents the results, and the final section concludes.

\section{Data}

In March 2020 the Illinois Commerce Commission (ICC) issued 20-NOI-01, "Notice of Inquiry Regarding Energy Affordability." It requires public utilities to file monthly reports with the commission that document economic stress among customers. At the zip code level, utilities report outcomes including the number of residential customers who are behind on their bills, disconnections for nonpayment, and participation in programs that provide assistance to low-income households. ${ }^{2}$ The first submissions required historical tallies going back to 2013, and have since been updated monthly during the pandemic, though the reports through August were mostly zeroes due to moratoria on disconnections and non-payment fees. Recent submissions include additional information, including disconnection notices and statistics for commercial customers. This paper uses data from Commonwealth Edison (ComEd) and Ameren, the two largest electric utilities in the state, with nearly five million residential customer accounts between them.

Table 1 provides summary statistics of the utility data, focusing on the month of October from 2018-2020. ${ }^{3}$ Roughly $20 \%$ of customers were levied some form of fee for late payment in October 2020, regardless of customer class. Unfortunately, this statistic was not reported in prior years, so it is not possible to say whether this is unusually high. Disconnection notices were also not reported

\footnotetext{
${ }^{2}$ These programs are a combination of federal- and state-funded initiatives to provide heat and electricity bill assistance.

${ }^{3}$ I focus on October for these statistics because it is the last month before the winter/cold temperature shut-off moratoria kicked in, and a COVID-related moratorium was in effect through the summer of 2020. I use the years 2018-2020 because municipal aggregation programs affected the number of customers in earlier years (see Deryugina et al. (2020) for a recent evaluation of this episode), and zip code-level customer counts were only reported in 2020.
} 
pre-pandemic, but it is nonetheless worrisome that nearly $4 \%$ of residential customers and $2-3 \%$ of commercial and industrial customers were on the brink of disconnection in October. Comparisons with historical statistics are possible for residential disconnections, which nearly doubled in October 2020 for ComEd customers, and were six times historical averages in Ameren territory.

ComEd has begun reporting arrearage statistics, ${ }^{4}$ showing $10 \%$ of residential customers have balances past due, twice the rate of December 2019. The average arrearage amount among those behind on their bills has increased over $50 \%$, to about $\$ 300 /$ customer past due. Over $5 \%$ of commercial and industrial accounts are past due, with an average outstanding balance of $\$ 1200$. These balances add up to $\$ 120$ million in residential arrearage, and $\$ 29$ million due from commercial and industrial customers. This is a 65\% increase over ComEd's total arrearages in December 2019.

The rises in residential customers with deferred payment agreements were about four- and sixfold for ComEd and Ameren, respectively. There was also a large expansion in programs to assist low-income customers during the pandemic. $0.5 \%$ of customers were on such programs in 2018-2019, while over $4 \%$ participated in 2020. An important part of low-income assistance programs involves debt forgiveness, so it makes sense that a significant share of customers on these programs were also deferring payment to future dates. A curiously high $11 \%$ of ComEd customers on low-income assistance were served disconnection notices in October 2020, while the analogous figure was less than $1 \%$ for Ameren customers. This is also striking because Illinois utilities ostensibly extended their disconnection moratoria through March 2021 to customers who call the utility and claim economic hardship (Crawford (2020)).

Figure 1 shows that there has been an unprecedented increase in difficulty paying utility bills during the COVID-19 pandemic. It plots aggregate statistics for the three outcomes that are reported by both ComEd and Ameren back to 2013. The totals are expressed as a percent of the number of residential customer accounts in 2020, as Ameren does not report historical customer counts (and neither utility reports the historical number of accounts at the zip code level). Data in 2020 are only reported in June and September-November. There are strong seasonal trends in all three outcomes. Assistance for low-income households is concentrated in the winter months, particularly during winter disconnection moratoria. ${ }^{5}$ Deferred payment agreements peak once winter moratoria are lifted. There is strong evidence that these moratoria are binding, with large increases in disconnections each April. The historical patterns are entirely disrupted with the onset of the COVID-19 pandemic. In line with the summary statistics in Table 1, assistance, deferred liabilities, and disconnections are all multiples of their historical averages in 2020.

The wide dispersion of these outcomes is evident in Figure 2, which presents a snapshot of outcomes for October 2020. For disconnections, there are 28 zip codes (with 16,000 customers) where over $4 \%$ of residential customers were disconnected in October, while 172 zip codes (with over 25,000 customers) had none at all. The figure also makes clear that Ameren has been more aggressively disconnecting customers in 2020 than ComEd overall: The mid-state break in disconnection rates corresponds to the territorial boundary between the companies. The south and west sides of Chicago are hard-hit relative to the surrounding suburbs, but there are zip codes throughout the state with comparable outcomes, or worse. For disconnection notices, there are roughly similar numbers of

\footnotetext{
${ }^{4}$ At the time of writing, the ICC has added arrearage statistics to their monthly requests, but only ComEd has submitted current statistics, covering the month of December for 2019 and 2020.

${ }^{5}$ Shutoffs in Illinois are forbidden annually between December and March, as well as when the temperature is forecast to drop below $32^{\circ} \mathrm{F}$, or exceed $95^{\circ} \mathrm{F}$ during the 24 -hour period in which the disconnection is scheduled.
} 
people $(100,000)$ in zip codes with more than $10 \%$ and less than $1 \%$ on notice. In panel $(\mathrm{B})$, the widespread prevalence of customers behind on their electricity bills is striking. With one out of five households levied late fees overall, about 200,000 people live in zip codes where the number is one out of three.

To explore the distributional incidence of these hardships, I merge the utility reports with zip code-level demographic and economic characteristics from the U.S. Census Bureau's American Community Survey (ACS). These estimates are based on data collected between 2015 and 2019, and were released in December, 2020. Table 2 presents summary statistics separately for Ameren and ComEd service territories, with statistics weighted by the number of residential customers in 2020. ComEd serves the Chicagoland area, with roughly three times the population spanning one third as many counties as Ameren. It has a larger minority composition, and the economy is more service sectororiented, with much less agriculture than downstate. ComEd zip codes have roughly similar shares of households earning less than $\$ 15,000$ /year, but double the share earning more than $\$ 150,000 /$ year. All told, the data reported to the Illinois Commerce Commission span over 1,300 zip codes in 111 counties. 
Table 1: October Summary Statistics from Illinois Utilities

\begin{tabular}{|c|c|c|c|c|}
\hline & $\begin{array}{r}\text { Commercial } \\
2020\end{array}$ & $\begin{array}{r}\text { All Residential } \\
2020\end{array}$ & $\begin{array}{r}\text { All Residential } \\
2018,2019\end{array}$ & $\begin{array}{r}\text { Low-Income } \\
\text { Residential } \\
2020\end{array}$ \\
\hline \multicolumn{5}{|l|}{ A. Commonwealth Edison } \\
\hline \multirow{2}{*}{$\%$ Levied Late Fees } & 21.11 & 17.23 & & 1.72 \\
\hline & {$[5.23]$} & {$[7.36]$} & & {$[1.55]$} \\
\hline \multirow[t]{2}{*}{$\%$ Served Disconnection Notice } & 1.66 & 3.64 & & 11.30 \\
\hline & {$[0.95]$} & {$[2.54]$} & & {$[4.93]$} \\
\hline \multirow[t]{2}{*}{$\%$ Disconnected for Non-Payment } & 0.54 & 0.85 & 0.48 & 0.75 \\
\hline & {$[0.51]$} & {$[0.76]$} & {$[0.38]$} & {$[0.79]$} \\
\hline \multirow[t]{2}{*}{$\%$ Balances Past Due } & 5.90 & 10.05 & 4.78 & 14.16 \\
\hline & {$[2.92]$} & {$[6.20]$} & {$[6.48]$} & {$[7.98]$} \\
\hline \multirow{2}{*}{ Average Arrears } & 1199.49 & 306.83 & 185.01 & 426.91 \\
\hline & {$[1359.73]$} & [91.14] & {$[61.28]$} & [140.32] \\
\hline \multirow[t]{2}{*}{$\%$ on Deferred Payment } & & 4.19 & 1.36 & 13.25 \\
\hline & & {$[3.12]$} & {$[1.09]$} & {$[5.84]$} \\
\hline \multirow[t]{2}{*}{$\%$ on Low-Income Program } & & 3.85 & 0.14 & \\
\hline & & {$[3.61]$} & {$[0.23]$} & \\
\hline Customers (thousands) & 380 & 3695 & & 142 \\
\hline \multicolumn{5}{|l|}{ B. Ameren } \\
\hline \multirow[t]{2}{*}{ \% Levied Late Fees } & 20.97 & 20.30 & & 8.86 \\
\hline & {$[5.12]$} & {$[5.60]$} & & {$[4.14]$} \\
\hline \multirow[t]{2}{*}{ \% Served Disconnection Notice } & 3.06 & 4.05 & & 0.76 \\
\hline & {$[1.50]$} & {$[1.57]$} & & {$[1.10]$} \\
\hline \multirow{2}{*}{$\%$ Disconnected for Non-Payment } & 0.31 & 1.26 & 0.20 & 0.94 \\
\hline & {$[0.35]$} & {$[0.80]$} & {$[0.19]$} & {$[1.14]$} \\
\hline \multirow[t]{2}{*}{$\%$ on Deferred Payment } & 0.54 & 7.09 & 1.13 & 18.66 \\
\hline & {$[0.74]$} & {$[3.86]$} & {$[0.73]$} & {$[7.33]$} \\
\hline \multirow[t]{2}{*}{$\%$ on Low-Income Program } & & 6.12 & 1.50 & \\
\hline & & {$[4.19]$} & {$[1.38]$} & \\
\hline \multirow[t]{2}{*}{ Average Arrears } & & & 426.87 & \\
\hline & & & {$[157.11]$} & \\
\hline Customers (thousands) & 212 & 1164 & & 71 \\
\hline
\end{tabular}

Note: Zip code level data are weighted by customer counts in 2020. Missing cells indicate non-reporting of the indicated statistic. All data are from October of the indicated year except arrears in ComEd territory, which is reported in December of 2019 and 2020 only. Standard deviations in brackets. 
Figure 1: Monthly Residential Outcomes in ComEd and Ameren Service Areas as a Percent of 2020 Accounts: 2013-2020

(A) Low-Income Program Participants

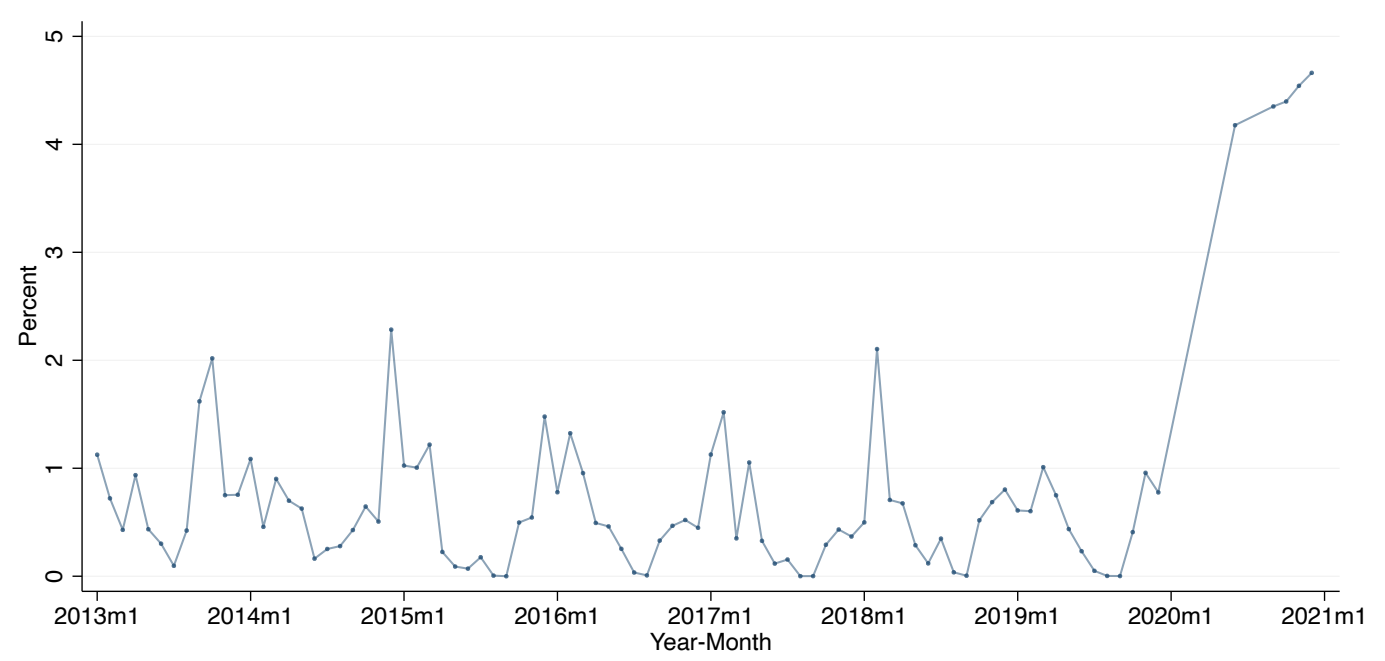

(B) Accounts with Deferred-Payment Arrangements

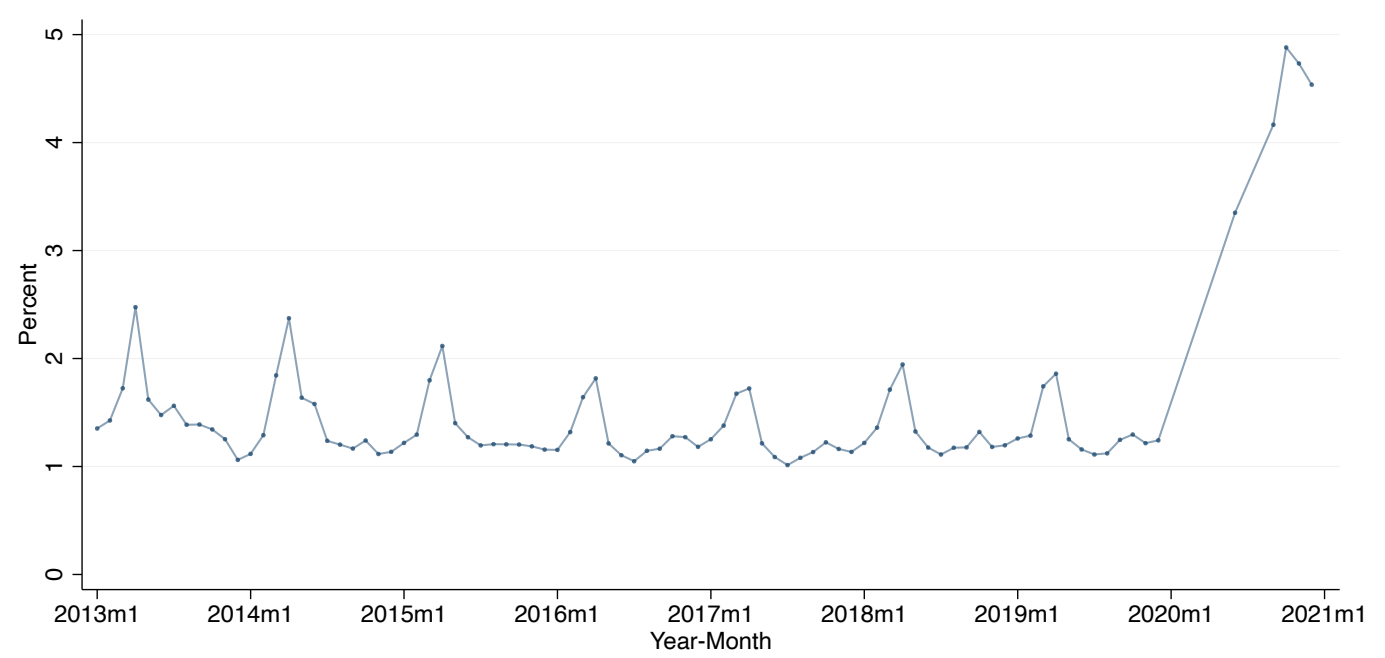

(C) Disconnections for Non-Payment

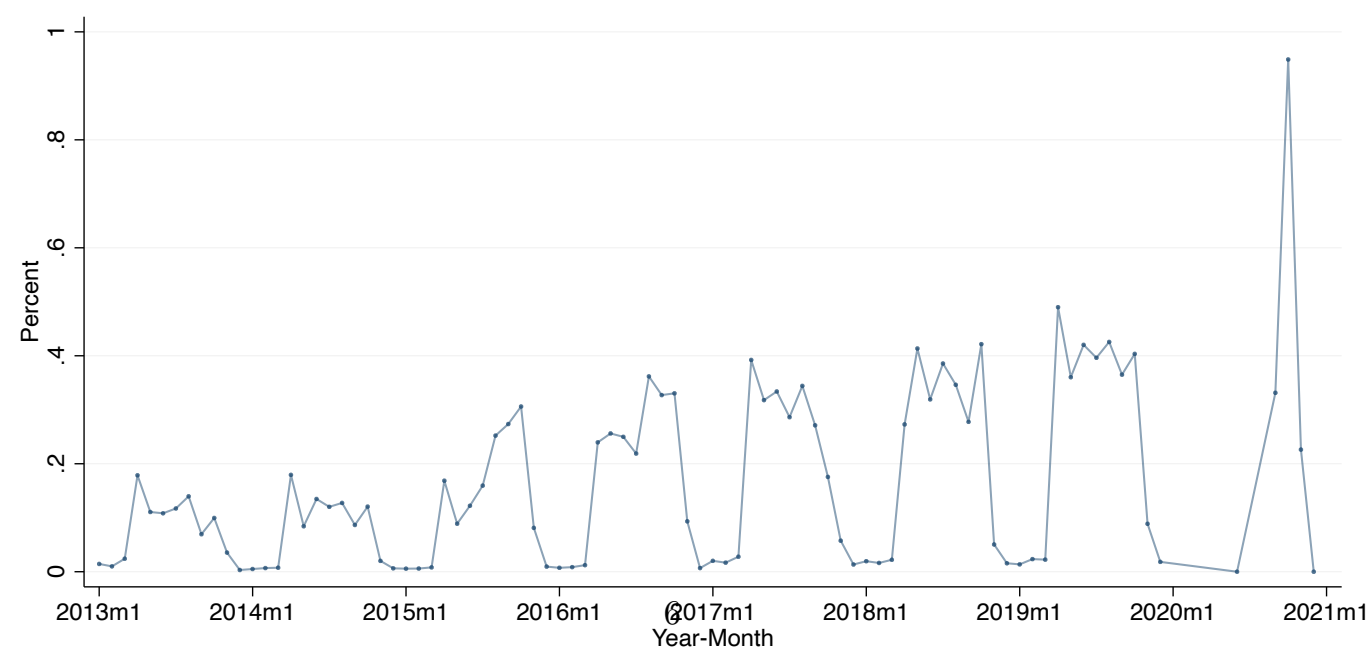


Figure 2: Percent of Residential Accounts Behind on Electricity Bills in October 2020 by Zip Code

(A) Disconnections
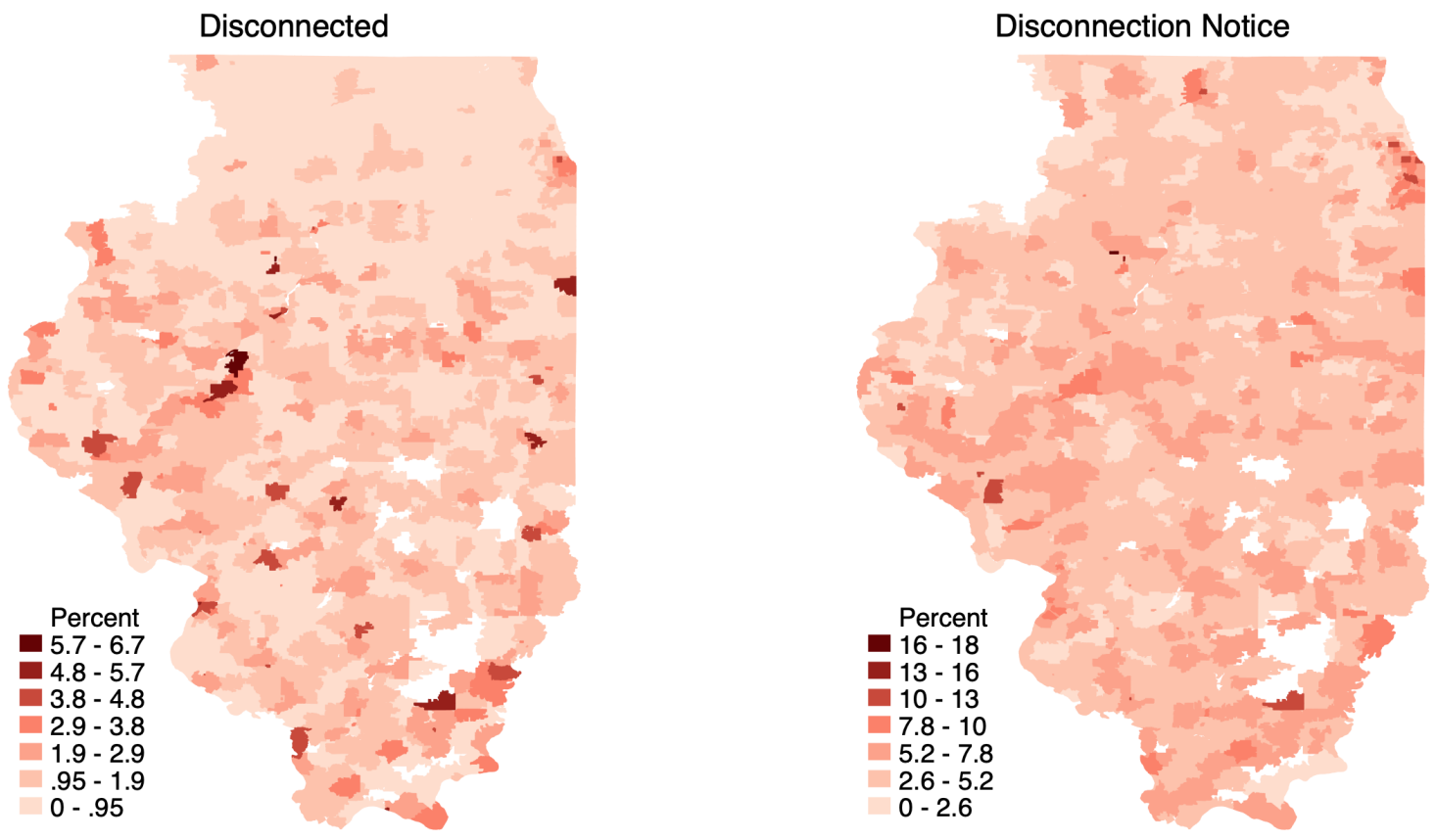

(B) Payments

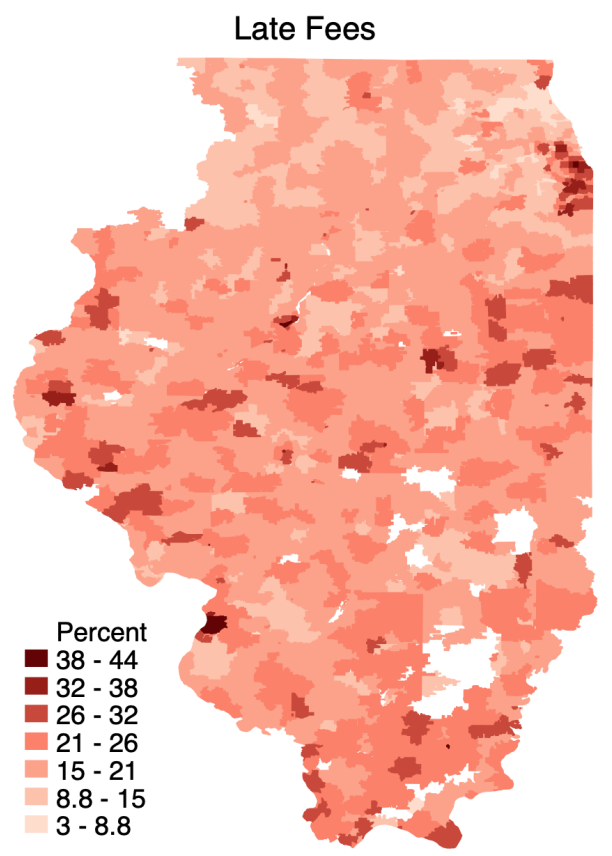

\section{Deferred-Payment Agreement}

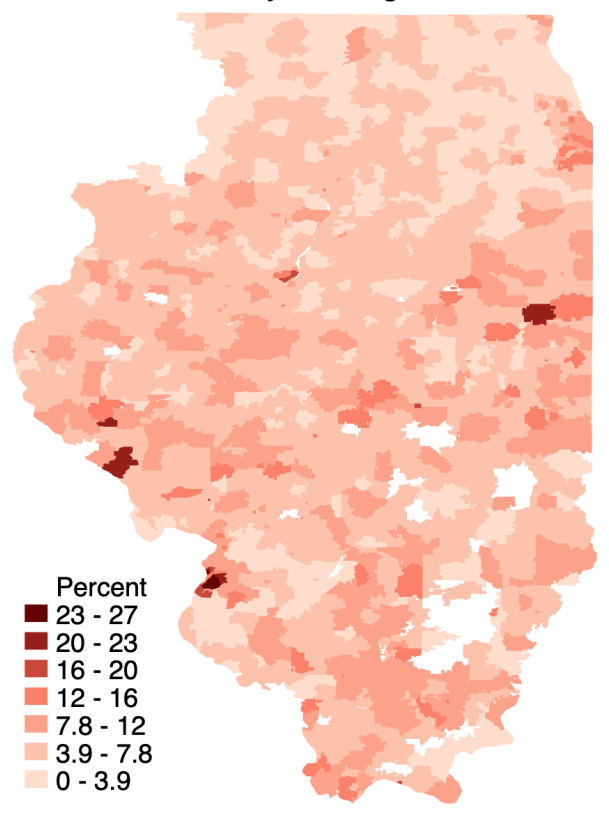


Table 2: Household Summary Statistics from the 2015-2019 American Community Survey

\begin{tabular}{|c|c|c|}
\hline \multirow[b]{2}{*}{ A. Demographics } & Ameren & \multirow[t]{2}{*}{ Commonwealth Edison } \\
\hline & & \\
\hline \multirow{3}{*}{$\%$ Black } & (1) & $(2)$ \\
\hline & 10.84 & 17.73 \\
\hline & [14.12] & {$[25.21]$} \\
\hline \multirow[t]{2}{*}{ \% Hispanic: Any Race } & 3.73 & 20.36 \\
\hline & {$[3.64]$} & [19.13] \\
\hline \multirow{2}{*}{$\%$ Non-Citizen | Over 18} & 2.33 & 10.47 \\
\hline & {$[3.30]$} & {$[8.28]$} \\
\hline \multirow[t]{2}{*}{ Median Age } & 39.90 & 38.13 \\
\hline & {$[5.77]$} & {$[4.88]$} \\
\hline \multirow[t]{2}{*}{ Household Size } & 2.48 & 2.68 \\
\hline & {$[0.26]$} & {$[0.39]$} \\
\hline \multirow[t]{2}{*}{ Children under 15 per Household } & 0.44 & 0.50 \\
\hline & {$[0.11]$} & {$[0.16]$} \\
\hline \multirow{2}{*}{ Adults over 65 per Household } & 0.43 & 0.38 \\
\hline & {$[0.10]$} & {$[0.12]$} \\
\hline \multicolumn{3}{|l|}{ B. Economy } \\
\hline \multirow[t]{2}{*}{$\%$ Agriculture } & 2.56 & 0.48 \\
\hline & {$[3.18]$} & {$[1.39]$} \\
\hline \multirow[t]{2}{*}{$\%$ Construction } & 5.48 & 5.06 \\
\hline & {$[2.83]$} & {$[2.52]$} \\
\hline \multirow[t]{2}{*}{$\%$ Manufacturing } & 11.97 & 11.55 \\
\hline & {$[5.53]$} & {$[5.16]$} \\
\hline \multirow[t]{2}{*}{$\%$ Services } & 55.26 & 59.39 \\
\hline & {$[9.41]$} & {$[9.97]$} \\
\hline \multirow[t]{2}{*}{$\%$ Other Industries } & 24.74 & 23.52 \\
\hline & {$[5.38]$} & {$[5.36]$} \\
\hline \multirow[t]{2}{*}{ Median Income ( thousands ) } & 56.83 & 75.13 \\
\hline & {$[17.28]$} & {$[28.58]$} \\
\hline \multirow[t]{2}{*}{$\%$ Receiving SNAP Benefits } & 13.71 & 12.67 \\
\hline & {$[7.96]$} & [10.14] \\
\hline \multirow{2}{*}{$\% \mathrm{HH}$ income $<\$ 15,000$} & 12.18 & 9.61 \\
\hline & {$[7.33]$} & {$[6.37]$} \\
\hline \multirow[t]{2}{*}{$\% \mathrm{HH}$ income between $\$ 15,000$ and $\$ 35,000$} & 20.00 & 15.99 \\
\hline & {$[5.90]$} & {$[6.84]$} \\
\hline \multirow[t]{2}{*}{$\% \mathrm{HH}$ income between $\$ 35,000$ and $\$ 75,000$} & 31.79 & 27.09 \\
\hline & {$[5.56]$} & {$[6.20]$} \\
\hline \multirow[t]{2}{*}{$\% \mathrm{HH}$ income between $\$ 75,000$ and $\$ 150,000$} & 26.83 & 29.44 \\
\hline & {$[7.70]$} & {$[7.01]$} \\
\hline \multirow{2}{*}{$\% \mathrm{HH}$ income $>=\$ 150,000$} & 9.20 & 17.88 \\
\hline & {$[6.30]$} & [12.07] \\
\hline Zip Codes & 853 & 460 \\
\hline Counties & 86 & 25 \\
\hline Households (thousands) & 1282 & 3473 \\
\hline
\end{tabular}

Note: Zip code level data are weighted by residential utility customer counts in 2020. Standard deviations in brackets. 


\section{Methods}

I evaluate how indicators of economic stress correlate with zip code demographic and economic characteristics. This is a descriptive analysis using cross-sectional variation in differences across zip codes to estimate disproportionate burdens, holding the distribution of income fixed.

At the individual account level, these indicators are binary outcomes: either an account is disconnected for non-payment, or it is not. Each zip code $c$ in month $t$ has $n_{c t}$ residential accounts, and there are $y_{c t}$ accounts that experience the outcome of interest. Assuming that outcomes are determined by zip code characteristics $\mathbf{X}_{c t}$ and a logistic error term yields the log likelihood function:

$$
l(\beta)=\left[\sum_{c} \sum_{t}\left(y_{c t} \ln \left(\frac{\exp \left(\mathbf{X}_{c t} \beta\right)}{1+\exp \left(\mathbf{X}_{c t} \beta\right)}\right)+\left(n_{c t}-y_{c t}\right) \ln \left(\frac{1}{1+\exp \left(\mathbf{X}_{c t} \beta\right)}\right)\right)\right]
$$

I estimate equation (1) via maximum likelihood separately for pre- and post-pandemic periods. Reported odds ratios are calculated as $e^{\hat{\beta}_{j}}$. For characteristics expressed as shares, this represents the predicted relative odds between a zip code entirely composed of the characteristic of interest and one completely lacking. Note that the odds ratio is invariant to the levels of the other neighborhood characteristics. ${ }^{6}$ Estimates regarding the share of the population within household income bins are estimated relative to the share of households earning between $\$ 35,000-75,000$ to avoid perfect collinearity.

Because the probability of each outcome of interest has changed significantly during the pandemic, changes in odds ratios do not reflect changes in the disproportionate burdens experienced by various groups. I therefore also report marginal probabilities, or the predicted change in probabilities when characteristic $x_{j}$ goes from zero to one, and the other characteristics are held at their sample means. ${ }^{7}$

To allow for within-county correlation in outcomes (due, for example, to county-level differences in policy), I calculate standard errors clustered at the county level. Results report $95 \%$ confidence intervals, which are asymmetric around the logit point estimates. They are based on the clustered standard errors.

\section{Results}

Table 3 presents estimates for neighborhood correlates with participation in utility-based low-income assistance programs. The mean probabilities at the bottom of the table reflect the massive expansion during the COVID-19 pandemic, going from 0.5\% during 2018-2019 to $4.5 \%$ during the reported months of 2020. Zip codes with larger fractions of high income households are, of course, negatively associated with participation, with marginal probabilities predicting essentially zero enrollees in wealthy neighborhoods. The odds of participation are much higher in lower income neighborhoods, thought he standard errors are quite large. Minority neighborhoods were about $70 \%$ more likely to

\footnotetext{
${ }^{6}$ With a logistic distribution, the log odds are
}

$$
\log \left[\frac{p}{1-p}\right]=\beta_{0}+x_{1} \beta_{1}+\ldots x_{k} \beta_{k}
$$

The odds ratio between $x_{j}=1$ and $x_{j}=0$ is the exponentiated difference in log odds, which is $e^{\beta_{j}}$ so long as the other characteristics are held fixed in the comparison.

${ }^{7}$ Letting $\overline{\mathbf{X}}_{-j}$ denote the sample means of characteristics other than $j$, the predicted change in probability when $x_{j}$ goes from zero to one is

$$
\Delta \hat{p}_{j}=\frac{e^{\overline{\mathbf{X}}_{-j} \beta_{-j}+\beta_{j}}}{1+e^{\overline{\mathbf{X}}_{-j} \beta_{-j}+\beta_{j}}}-\frac{e^{\overline{\mathbf{X}}_{-j} \beta_{-j}}}{1+e^{\overline{\mathbf{X}}_{-j} \beta_{-j}}}
$$


participate in these programs, while larger shares of non-citizens are less likely to receive benefits. Relationships with the other demographic variables are all modest and not statistically different from zero. Controlling for demographic differences, ComEd was about half likely to provide assistance under these programs before 2020. Comparing earlier years with the pandemic, the relative likelihood across groups is strikingly similar, while the breadth of participation has widely expanded.

Table 4 finds that deferred payment agreements (DPAs) are also more common in minority neighborhoods, though not with the share of non-citizens. While the lowest income neighborhoods appear less likely to have DPAs, they are employed more often in zip codes with more children per household. The expansion of DPAs in 2020 amounts to a significant rise in debt owed by these households. An additional 4-6\% of households in minority neighborhoods would be sufficiently behind on their electricity bill to require deferred payment.

Table 5 presents the main estimates for residential electricity disconnections. All estimates are based on the month of October to keep estimates comparable across years with various disconnection moratoria in place during 2020. Controlling for the income distribution and other demographics, customers in minority neighborhoods were four to five times more likely to have their power disconnected, both in normal times and during the COVID-19 pandemic. An additional 2\% of accounts are estimated to have been disconnected in minority zip codes, all else equal (over a mean of $0.9 \%$ in Illinois). It is also interesting that low-income zip codes are not more likely to be disconnected during the pandemic, relative to neighborhoods with earners between $\$ 35,000-75,000$. The combined forces of expanded assistance to low-income households and disconnections in middle-income zip codes has worked to essentially eliminate the gradient that exists in normal times. High income zip codes continue to have few disconnections, if any. Disconnection policies between utilities appear to have changed during the pandemic, as ComEd used to be nearly twice as likely to disconnect residential accounts, but has been $40 \%$ less likely during the pandemic.

In the final two tables I examine correlates of disconnection notices and fees, and am able to include commercial and industrial accounts in the analysis. These outcomes were not provided in the historical data submissions, so I am unable to say how these relationships have changed during COVID-19 relative to historical averages. Both tables show a continued pattern for low-income and minority communities of being disproportionately likely to have trouble paying electric bills. Businesses in these communities are also more likely to be behind on utility bills, on the order of 2-4 times more likely in Black and Hispanic zip codes. Interestingly, commercial accounts in zip codes with high shares of non-citizens are also modestly more likely to be served disconnection notices and charged late fees, while this characteristic is otherwise negatively associated with non-payment for residential accounts.

\section{Discussion}

In 2019, the National Association of Regulatory Utility Commissioners codified a set of best practices for the collection and dissemination of data on utility arrearages, disconnections, and low-income assistance participation (NARUC (2019)). The Illinois Commerce Commission has recently applied these principles, making available a wealth of data by zip code and month. As major real-time economic data collection efforts are underway (U.S. Census Bureau (2020b); Buffington et al. (2020); Han et al. (2020)), utility disconnections provide a valuable complementary resource. These data are the by-product of utilities' standard accounting operations, and generally not subject to business confidential dissemination constraints. Provided at the zip code level, they allow finer geographic 
Table 3: Low Income Assistant Participation, September-December

\begin{tabular}{|c|c|c|c|c|}
\hline & \multicolumn{2}{|c|}{ 2018-2019 } & \multicolumn{2}{|c|}{2020} \\
\hline & Odds Ratio & $\begin{array}{r}\text { Marginal } \\
\text { Probability }\end{array}$ & Odds Ratio & $\begin{array}{r}\text { Marginal } \\
\text { Probability }\end{array}$ \\
\hline & $(1)$ & $(2)$ & $(3)$ & (4) \\
\hline \multirow[t]{2}{*}{ ComEd Territory } & 0.453 & -0.004 & 0.728 & -0.011 \\
\hline & {$[0.340,0.602]$} & & {$[0.582,0.911]$} & \\
\hline \multirow[t]{2}{*}{ Share Black } & 1.681 & 0.002 & 2.366 & 0.038 \\
\hline & {$[1.027,2.752]$} & & {$[1.578,3.548]$} & \\
\hline \multirow[t]{2}{*}{ Share Hispanic: Any Race } & 1.724 & 0.002 & 2.052 & 0.030 \\
\hline & {$[1.036,2.869]$} & & {$[1.461,2.884]$} & \\
\hline \multirow[t]{2}{*}{ Share Non-Citizen | Over 18} & 0.402 & -0.002 & 0.462 & -0.019 \\
\hline & {$[0.181,0.895]$} & & {$[0.246,0.869]$} & \\
\hline \multirow[t]{2}{*}{ Median Age } & 1.000 & -0.000 & 1.003 & 0.000 \\
\hline & {$[0.981,1.019]$} & & {$[0.991,1.016]$} & \\
\hline \multirow[t]{2}{*}{ Household Size } & 0.748 & -0.002 & 0.957 & -0.002 \\
\hline & {$[0.474,1.182]$} & & {$[0.638,1.434]$} & \\
\hline \multirow[t]{2}{*}{ Children under 15 per Household } & 0.886 & -0.000 & 0.889 & -0.004 \\
\hline & {$[0.307,2.556]$} & & {$[0.298,2.655]$} & \\
\hline \multirow[t]{2}{*}{ Adults over 65 per Household } & 0.979 & -0.000 & 1.035 & 0.001 \\
\hline & {$[0.407,2.352]$} & & {$[0.643,1.665]$} & \\
\hline \multirow[t]{2}{*}{ Share HH income $<15,000$} & 2.105 & 0.004 & 2.736 & 0.050 \\
\hline & {$[0.465,9.541]$} & & {$[0.816,9.176]$} & \\
\hline \multirow{2}{*}{$\begin{array}{l}\text { Share HH income between } 15,000 \text { and } \\
35,000\end{array}$} & 8.303 & 0.018 & 10.026 & 0.171 \\
\hline & {$[2.760,24.975]$} & & {$[4.292,23.420]$} & \\
\hline \multirow{2}{*}{$\begin{array}{l}\text { Share HH income between } 75,000 \text { and } \\
150,000\end{array}$} & 0.043 & -0.008 & 0.122 & -0.053 \\
\hline & {$[0.011,0.169]$} & & {$[0.033,0.455]$} & \\
\hline \multirow[t]{2}{*}{ Share HH income $>=150,000$} & 0.075 & -0.005 & 0.060 & -0.049 \\
\hline & {$[0.023,0.242]$} & & {$[0.027,0.133]$} & \\
\hline Mean Probability & 0.005 & 0.005 & 0.045 & 0.045 \\
\hline Zip Code-Months & 10208 & 10208 & 5108 & 5108 \\
\hline Customer-Months (thousands) & 38832 & 38832 & 19423 & 19423 \\
\hline
\end{tabular}

Note: $95 \%$ Confidence intervals in brackets are based on standard errors clustered at the county level. The mean probability is based on the overall share of account-months, while marginal probabilities are calculated as the difference in probabilities when the relevant explanatory variable equals one versus zero and all other variables are held at their sample means. Odds ratios are exponentiated logistic coefficients. 
Table 4: Residential Accounts with Deferred Payment Agreements, SeptemberDecember

\begin{tabular}{|c|c|c|c|c|}
\hline & \multicolumn{2}{|c|}{$2018-2019$} & \multicolumn{2}{|c|}{2020} \\
\hline & Odds Ratio & $\begin{array}{r}\text { Marginal } \\
\text { Probability }\end{array}$ & Odds Ratio & $\begin{array}{r}\text { Marginal } \\
\text { Probability }\end{array}$ \\
\hline & (1) & $(2)$ & $(3)$ & $(4)$ \\
\hline \multirow[t]{2}{*}{ ComEd Territory } & 1.433 & 0.003 & 0.632 & -0.018 \\
\hline & {$[1.210,1.696]$} & & {$[0.523,0.763]$} & \\
\hline \multirow[t]{2}{*}{ Share Black } & 2.980 & 0.016 & 3.309 & 0.064 \\
\hline & {$[2.293,3.874]$} & & {$[2.597,4.217]$} & \\
\hline \multirow{2}{*}{ Share Hispanic: Any Race } & 1.986 & 0.009 & 2.257 & 0.038 \\
\hline & {$[1.705,2.313]$} & & {$[1.705,2.988]$} & \\
\hline \multirow[t]{2}{*}{ Share Non-Citizen | Over 18} & 0.087 & -0.011 & 0.089 & -0.041 \\
\hline & {$[0.057,0.133]$} & & {$[0.051,0.155]$} & \\
\hline \multirow[t]{2}{*}{ Median Age } & 1.014 & 0.000 & 1.020 & 0.000 \\
\hline & {$[1.006,1.023]$} & & {$[1.010,1.030]$} & \\
\hline \multirow[t]{2}{*}{ Household Size } & 1.104 & 0.001 & 1.052 & 0.002 \\
\hline & {$[0.971,1.255]$} & & {$[0.908,1.219]$} & \\
\hline \multirow[t]{2}{*}{ Children under 15 per Household } & 2.594 & 0.010 & 3.035 & 0.041 \\
\hline & {$[1.843,3.650]$} & & {$[2.234,4.124]$} & \\
\hline \multirow[t]{2}{*}{ Adults over 65 per Household } & 0.403 & -0.008 & 0.403 & -0.030 \\
\hline & {$[0.283,0.573]$} & & {$[0.254,0.639]$} & \\
\hline \multirow[t]{2}{*}{ Share $\mathrm{HH}$ income $<15,000$} & 0.397 & -0.006 & 0.225 & -0.033 \\
\hline & {$[0.258,0.613]$} & & {$[0.136,0.374]$} & \\
\hline \multirow{2}{*}{$\begin{array}{l}\text { Share HH income between } 15,000 \text { and } \\
35,000\end{array}$} & 1.203 & 0.002 & 0.799 & -0.007 \\
\hline & {$[0.599,2.418]$} & & {$[0.311,2.048]$} & \\
\hline \multirow{2}{*}{$\begin{array}{l}\text { Share } \mathrm{HH} \text { income between } 75,000 \text { and } \\
150,000\end{array}$} & 0.566 & -0.005 & 0.301 & -0.035 \\
\hline & {$[0.181,1.764]$} & & {$[0.116,0.779]$} & \\
\hline \multirow[t]{2}{*}{ Share HH income $>=150,000$} & 0.014 & -0.019 & 0.015 & -0.068 \\
\hline & {$[0.007,0.025]$} & & {$[0.007,0.030]$} & \\
\hline Mean Probability & 0.012 & 0.012 & 0.046 & 0.046 \\
\hline Zip Code-Months & 10208 & 10208 & 5108 & 5108 \\
\hline Customer-Months (thousands) & 38832 & 38832 & 19423 & 19423 \\
\hline
\end{tabular}

Note: $95 \%$ Confidence intervals in brackets are based on standard errors clustered at the county level. The mean probability is based on the overall share of account-months, while marginal probabilities are calculated as the difference in probabilities when the relevant explanatory variable equals one versus zero and all other variables are held at their sample means. Odds ratios are exponentiated logistic coefficients. 
Table 5: Residential Accounts Disconnected for Non-Payment, October

\begin{tabular}{|c|c|c|c|c|}
\hline & \multicolumn{2}{|c|}{ 2018-2019 } & \multicolumn{2}{|c|}{2020} \\
\hline & Odds Ratio & $\begin{array}{r}\text { Marginal } \\
\text { Probability }\end{array}$ & Odds Ratio & $\begin{array}{r}\text { Marginal } \\
\text { Probability }\end{array}$ \\
\hline & $(1)$ & $(2)$ & $(3)$ & $(4)$ \\
\hline \multirow[t]{2}{*}{ ComEd Territory } & 1.834 & 0.002 & 0.598 & -0.005 \\
\hline & {$[1.501,2.242]$} & & {$[0.518,0.691]$} & \\
\hline \multirow[t]{2}{*}{ Share Black } & 3.876 & 0.008 & 4.130 & 0.019 \\
\hline & {$[2.956,5.082]$} & & {$[3.347,5.095]$} & \\
\hline \multirow[t]{2}{*}{ Share Hispanic: Any Race } & 5.666 & 0.012 & 3.908 & 0.017 \\
\hline & {$[4.182,7.676]$} & & {$[2.957,5.164]$} & \\
\hline \multirow[t]{2}{*}{ Share Non-Citizen | Over 18} & 0.271 & -0.003 & 0.176 & -0.007 \\
\hline & {$[0.115,0.639]$} & & {$[0.113,0.273]$} & \\
\hline \multirow[t]{2}{*}{ Median Age } & 1.007 & 0.000 & 1.013 & 0.000 \\
\hline & {$[0.994,1.020]$} & & {$[1.005,1.020]$} & \\
\hline \multirow[t]{2}{*}{ Household Size } & 1.146 & 0.000 & 0.997 & -0.000 \\
\hline & {$[0.880,1.492]$} & & {$[0.841,1.181]$} & \\
\hline \multirow[t]{2}{*}{ Children under 15 per Household } & 0.670 & -0.001 & 1.099 & 0.001 \\
\hline & {$[0.388,1.156]$} & & {$[0.712,1.696]$} & \\
\hline \multirow[t]{2}{*}{ Adults over 65 per Household } & 0.797 & -0.001 & 0.536 & -0.005 \\
\hline & {$[0.455,1.396]$} & & {$[0.338,0.852]$} & \\
\hline \multirow[t]{2}{*}{ Share HH income $<15,000$} & 2.294 & 0.004 & 0.584 & -0.003 \\
\hline & {$[1.022,5.147]$} & & {$[0.250,1.364]$} & \\
\hline \multirow{2}{*}{$\begin{array}{l}\text { Share HH income between } 15,000 \text { and } \\
35,000\end{array}$} & 1.407 & 0.001 & 0.966 & -0.000 \\
\hline & {$[0.309,6.400]$} & & {$[0.262,3.559]$} & \\
\hline \multirow{2}{*}{$\begin{array}{l}\text { Share HH income between } 75,000 \text { and } \\
150,000\end{array}$} & 0.536 & -0.002 & 0.116 & -0.013 \\
\hline & {$[0.232,1.238]$} & & {$[0.030,0.453]$} & \\
\hline \multirow[t]{2}{*}{ Share HH income $>=150,000$} & 0.385 & -0.002 & 0.096 & -0.010 \\
\hline & {$[0.190,0.782]$} & & {$[0.036,0.255]$} & \\
\hline Mean Probability & 0.004 & 0.004 & 0.009 & 0.009 \\
\hline Zip Code-Months & 2552 & 2552 & 1277 & 1277 \\
\hline Customer-Months (thousands) & 9708 & 9708 & 4854 & 4854 \\
\hline
\end{tabular}

Note: 95\% Confidence intervals in brackets are based on standard errors clustered at the county level. The mean probability is based on the overall share of account-months, while marginal probabilities are calculated as the difference in probabilities when the relevant explanatory variable equals one versus zero and all other variables are held at their sample means. Odds ratios are exponentiated logistic coefficients. 
Table 6: Accounts Served Disconnection Notices, September-December 2020

\begin{tabular}{|c|c|c|c|c|}
\hline & \multicolumn{2}{|c|}{ Commercial \& Industrial } & \multicolumn{2}{|c|}{ Residential } \\
\hline & Odds Ratio & $\begin{array}{r}\text { Marginal } \\
\text { Probability }\end{array}$ & Odds Ratio & $\begin{array}{r}\text { Marginal } \\
\text { Probability }\end{array}$ \\
\hline & $(1)$ & $(2)$ & $(3)$ & (4) \\
\hline \multirow[t]{2}{*}{ ComEd Territory } & 0.556 & -0.015 & 0.950 & -0.001 \\
\hline & {$[0.503,0.614]$} & & {$[0.840,1.074]$} & \\
\hline \multirow{2}{*}{ Share Black: Alone or in Combination } & 3.842 & 0.051 & 2.709 & 0.040 \\
\hline & {$[3.235,4.563]$} & & {$[2.265,3.241]$} & \\
\hline \multirow[t]{2}{*}{ Share Hispanic: Any Race } & 3.450 & 0.045 & 2.186 & 0.029 \\
\hline & {$[2.732,4.355]$} & & {$[1.885,2.535]$} & \\
\hline \multirow[t]{2}{*}{ Share Non-Citizen | Over 18} & 1.492 & 0.011 & 0.149 & -0.029 \\
\hline & {$[0.680,3.275]$} & & {$[0.104,0.213]$} & \\
\hline \multirow[t]{2}{*}{ Median Age } & 0.995 & -0.000 & 1.011 & 0.000 \\
\hline & {$[0.988,1.002]$} & & {$[1.002,1.020]$} & \\
\hline \multirow{2}{*}{ Household Size } & 0.837 & -0.006 & 1.006 & 0.000 \\
\hline & {$[0.706,0.993]$} & & {$[0.866,1.170]$} & \\
\hline \multirow[t]{2}{*}{ Children under 15 per Household } & 0.635 & -0.010 & 2.163 & 0.023 \\
\hline & {$[0.412,0.979]$} & & {$[1.550,3.019]$} & \\
\hline \multirow[t]{2}{*}{ Adults over 65 per Household } & 0.879 & -0.003 & 0.488 & -0.020 \\
\hline & {$[0.627,1.232]$} & & {$[0.357,0.666]$} & \\
\hline \multirow[t]{2}{*}{ Share HH income $<15,000$} & 0.949 & -0.001 & 0.366 & -0.021 \\
\hline & {$[0.420,2.145]$} & & {$[0.186,0.718]$} & \\
\hline \multirow{2}{*}{$\begin{array}{l}\text { Share HH income between } 15,000 \text { and } \\
35,000\end{array}$} & 1.742 & 0.015 & 1.040 & 0.001 \\
\hline & {$[0.809,3.754]$} & & {$[0.595,1.818]$} & \\
\hline \multirow{2}{*}{$\begin{array}{l}\text { Share HH income between } 75,000 \text { and } \\
150,000\end{array}$} & 0.907 & -0.002 & 0.251 & -0.032 \\
\hline & {$[0.395,2.085]$} & & {$[0.119,0.531]$} & \\
\hline \multirow[t]{2}{*}{ Share HH income $>=150,000$} & 1.510 & 0.011 & 0.058 & -0.043 \\
\hline & {$[0.802,2.842]$} & & {$[0.039,0.088]$} & \\
\hline Mean Probability & 0.025 & 0.025 & 0.034 & 0.034 \\
\hline Zip Code-Months & 5276 & 5276 & 5232 & 5232 \\
\hline Customer-Months (thousands) & 2362 & 2362 & 19435 & 19435 \\
\hline
\end{tabular}

Note: 95\% Confidence intervals in brackets are based on standard errors clustered at the county level. The mean probability is based on the overall share of account-months, while marginal probabilities are calculated as the difference in probabilities when the relavant explanatory variable equals one versus zero and all other variables are held at their sample means. Odds ratios are exponentiated logistic coefficients. 
Table 7: Accounts Levied Non-Payment Fees, September-December 2020

\begin{tabular}{|c|c|c|c|c|}
\hline & \multicolumn{2}{|c|}{ Commercial \& Industrial } & \multicolumn{2}{|c|}{ Residential } \\
\hline & Odds Ratio & $\begin{array}{r}\text { Marginal } \\
\text { Probability }\end{array}$ & Odds Ratio & $\begin{array}{r}\text { Marginal } \\
\text { Probability }\end{array}$ \\
\hline & (1) & $(2)$ & $(3)$ & (4) \\
\hline \multirow[t]{2}{*}{ ComEd Territory } & 0.823 & -0.033 & 0.718 & -0.049 \\
\hline & {$[0.759,0.893]$} & & {$[0.665,0.775]$} & \\
\hline \multirow[t]{2}{*}{ Share Black: Alone or in Combination } & 2.220 & 0.155 & 2.554 & 0.158 \\
\hline & {$[1.947,2.530]$} & & {$[2.302,2.833]$} & \\
\hline \multirow[t]{2}{*}{ Share Hispanic: Any Race } & 1.786 & 0.109 & 2.108 & 0.121 \\
\hline & {$[1.531,2.084]$} & & {$[1.892,2.349]$} & \\
\hline \multirow[t]{2}{*}{ Share Non-Citizen | Over 18} & 1.475 & 0.071 & 0.502 & -0.079 \\
\hline & {$[0.795,2.736]$} & & {$[0.332,0.758]$} & \\
\hline \multirow{2}{*}{ Median Age } & 0.997 & -0.001 & 1.007 & 0.001 \\
\hline & {$[0.992,1.002]$} & & {$[1.001,1.013]$} & \\
\hline \multirow[t]{2}{*}{ Household Size } & 0.903 & -0.019 & 0.941 & -0.009 \\
\hline & {$[0.833,0.980]$} & & {$[0.861,1.028]$} & \\
\hline \multirow[t]{2}{*}{ Children under 15 per Household } & 0.751 & -0.048 & 1.428 & 0.050 \\
\hline & {$[0.595,0.948]$} & & {$[1.199,1.701]$} & \\
\hline \multirow[t]{2}{*}{ Adults over 65 per Household } & 0.875 & -0.022 & 0.461 & -0.102 \\
\hline & {$[0.658,1.162]$} & & {$[0.374,0.569]$} & \\
\hline \multirow[t]{2}{*}{ Share $\mathrm{HH}$ income $<15,000$} & 1.556 & 0.082 & 0.945 & -0.008 \\
\hline & {$[0.951,2.545]$} & & {$[0.688,1.298]$} & \\
\hline \multirow{2}{*}{$\begin{array}{l}\text { Share HH income between } 15,000 \text { and } \\
35,000\end{array}$} & 2.432 & 0.173 & 1.116 & 0.016 \\
\hline & {$[1.137,5.201]$} & & {$[0.792,1.571]$} & \\
\hline \multirow{2}{*}{$\begin{array}{l}\text { Share HH income between } 75,000 \text { and } \\
150,000\end{array}$} & 1.530 & 0.075 & 0.489 & -0.090 \\
\hline & {$[0.720,3.254]$} & & {$[0.366,0.653]$} & \\
\hline \multirow[t]{2}{*}{ Share HH income $>=150,000$} & 1.768 & 0.106 & 0.145 & -0.175 \\
\hline & {$[1.072,2.915]$} & & {$[0.105,0.200]$} & \\
\hline Mean Probability & 0.215 & 0.215 & 0.176 & 0.176 \\
\hline Zip Code-Months & 5276 & 5276 & 5232 & 5232 \\
\hline Customer-Months (thousands) & 2362 & 2362 & 19435 & 19435 \\
\hline
\end{tabular}

Note: $95 \%$ Confidence intervals in brackets are based on standard errors clustered at the county level. The mean probability is based on the overall share of account-months, while marginal probabilities are calculated as the difference in probabilities when the relavant explanatory variable equals one versus zero and all other variables are held at their sample means. Odds ratios are exponentiated logistic coefficients. 
detail than statistical surveys without compromising customer privacy. Although these data have little to say about homeless populations (as is the case for many benchmark consumption surveys (Meyer et al. (2021))), they provide greater coverage of groups that lack access to traditional banking or electronic payments.

The picture that emerges from Illinois is a troubling one. Nearly 50,000 residential customers were disconnected for non-payment in October 2020, in spite of a voluntary moratorium that would exempt households experiencing financial hardship. Over 16,000 customers live in zip codes where more than $4 \%$ of households were disconnected that month. There is a strong neighborhood income gradient to these outcomes. Even after accounting for the distribution of income, these burdens fall disproportionately on minority communities - both in normal times and during COVID-19. Looking forward, $3.4 \%$ of residences and $2.5 \%$ of businesses were served disconnection notices on a monthly basis in late 2020 before the regular winter disconnection moratorium began in December. An additional 3-5\% of residences and businesses in minority zip codes is estimated to have received disconnection notices each month in late 2020. With deferred payment agreements accumulating balances due and higher residential consumption during the pandemic (Cicala (2020)), there is a significant risk of mass disconnection when moratoria expire at the end of March, 2021. 


\section{References}

Barreca, Alan I., Karen Clay, Olivier Deschênes, Michael Greenstone, and Joseph S. Shapiro, "Adapting to Climate Change: The Remarkable Decline in the US TemperatureMortality Relationship over the 20th Century," Journal of Political Economy, 2016, 124 (1), $105-159$.

Baum, Matthew A, Jennifer Lin, David Lazer, Katherine Ognyanova, Roy H Perlis, James Druckman, Mauricio Santillana, Alexi Quintana, Matthew Simonson, Jon Green, Ata A Uslu, Adina Gitomer, and Hanyu Chwe, "THE COVID STATES PROJECT : A 50-STATE COVID-19 SURVEY REPORT \#30: ECONOMIC HARDSHIPS DUE TO THE COVID-19 PANDEMIC," Technical Report 2020.

Bitler, Marianne, Hilary W. Hoynes, and Diane Whitmore Schanzenbach, "The Social Safety Net in the Wake of COVID-19," 2020.

Buffington, Catherine, Carrie Dennis, Emin Dinlersoz, Lucia Foster, and Shawn Klimek, "Measuring the Effect of COVID-19 on U.S. Small Businesses: The Small Business Pulse Survey," 2020.

Carley, Sanya and David M. Konisky, "Survey of Household Energy Insecurity in Time of COVID," Technical Report, Indiana University 2020.

Chetty, Raj, John N Friedman, Nathaniel Hendren, and Michael Stepner, "The Economic Impacts of COVID-19: Evidence from a New Public Database Built from Private Sector Data," 2020 .

Chirakijja, Janjala, Seema Jayachandran, and Pinchuan Ong, "Inexpensive Heating Reduces Winter Mortality," 2020.

Cicala, Steve, "Powering Work from Home," 2020.

Couch, Kenneth A., Robert W. Fairlie, and Huanan Xu, "Early evidence of the impacts of COVID-19 on minority unemployment," Journal of Public Economics, 2020, 192, 104287.

Cox, Natalie, Peter Ganong, Pascal Noel, Joseph Vavra, Arlene Wong, Diana Farrell, and Fiona Greig, "Initial Impacts of the Pandemic on Consumer Behavior: Evidence from Linked Income, Spending, and Savings Data," Brookings Papers on Economic Activity, 2020, (June).

Crawford, Victoria, "State Regulated Utility Moratorium Extended through Winter 2021 for Eligible Customers," 2020.

Deryugina, Tatyana, Alexander Mackay, and Julian Reif, "The Long-Run Dynamics of Electricity Demand : Evidence from Municipal Aggregation," American Economic Journal: Applied Economics, 2020, 12 (1), 86-114.

Graff, Michelle and Sanya Carley, "COVID-19 assistance needs to target energy," Nature Energy, 2020, 5 (May), 352-354.

Han, Jeehoon, Bruce D. Meyer, and James X. Sullivan, "Income and Poverty in the COVID19 Pandemic," 2020. 
Jowers, Kay, Christopher Timmins, Nrupen Bhavsar, Qihui Hu, and Julia Marshall, "Housing Precarity \& the COVID-19 Pandemic: Impacts of Utility Disconnection and Eviction Moratoria on Infections and Deaths Across US Counties," 2021.

Medalia, C, Bruce D. Meyer, A. O'Hara, and Derek Wu, "Linking Survey and Administrative Data to Measure Income, Inequality, and Mobility," International Journal of Population Data Science, 2019, 4 (January).

Meyer, Bruce D. and James X. Sullivan, "Measuring the Well-Being of the Poor Using Income and Consumption," The Journal of Human Resources, 2003, 38 (Special Issue on Income Volatility and Implications for Food Assistance Programs), 1180-1220.

_ , Derek Wu, Victoria R. Mooers, and Carla Medalia, "The Use and Misuse of Income Data and Extreme Poverty in the United States," Journal of Labor Economics, 2021, 39 (S1), S5-S58.

_ , Wallace K. C. Mok, and James X. Sullivan, "Household Surveys in Crisis," Journal of Economic Perspectives, 2015, 29 (4), 199-226.

NARUC, "Resolution on Best Practices in Data Collection and Reporting for Utility Services Delinquencies in Payments and Disconnections of Service Whereas," 2019.

U.S. Census Bureau, "2015-2019 American Community Survey 5-year Detailed Tables," 2020.

_ , "Household Pulse Survey Data Tables," 2020.

Wright, Austin L, Konstantin Sonin, Jesse Driscoll, and Jarnickae Wilson, "Poverty and Economic Dislocation Reduce Compliance with COVID-19 Shelter-in-Place Protocols," Journal of Economic Behavior and Organization, 2020, 180 (Dec), 544-554. 